\title{
PERAN GEREJA DALAM PELAYANAN PASTORAL TERHADAP PASANGAN HAMIL SEBELUM MENIKAH
}

\author{
Jonidius Illu \\ Prodi Teologi, Sekolah Tinggi Injili Arastamar (STT SETIA) Jakarta \\ joillu@sttsetia.ac.id
}

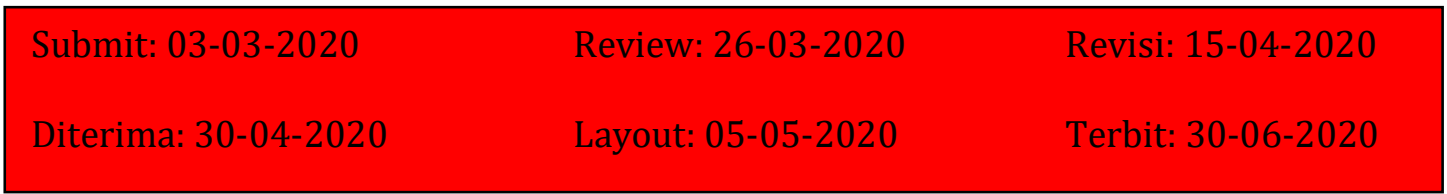

\begin{abstract}
One focus of church service is to prepare Christian families who live righteously through premarital counseling.Marriage is prepared for a lifetime.One of the efforts of the church in realizing church members who live holy lives is by giving teachings about love and choosing a partner according to the Bible so that church members do not commit adultery and sexual intercours outside of marriage which results in pregnancy outside of marriage. This study aims to understand marriage and build a Christian family that is in accordance with the Bible and provide understanding that having sexual relation not within the container of Christian marriage is adultery so that both men and women need to confess their sins before God. It was concluded that the Church is responsible for providing pastoral care to couples who become pregnant out of wedlock.The church in carrying out the principle of love still observes the rules so that the maturity of the church members become realized.
\end{abstract}

Key Words: Counseling; Pastoral; Marriage; Couple; Premarital

\begin{abstract}
Abstrak
Salah satu fokus pelayanan gereja adalah mempersiapkan keluarga Kristen yang hidup benar melalui konseling pranikah. Perkawinan dipersiapkan untuk seumur hidup. Upaya gereja dalam mewujudkan warga gereja yang hidup kudus salah satunya adalah dengan memberi pengajaran tentang cinta dan memilih pasangan yang sesuai Alkitab sehingga warga gereja tidak melakukan dosa perzinahan dan melakukan hubungan seksual diluar pernikahan yang berdampak terjadinya kehamilan di luar pernikahan. Metode pengumpulan data melalui studi kepustakaan, wawancara, kepada beberapa orang yang menjadi partisipan dalam penelitian ini. Penelitian ini bertujuan agar mengerti tentang pernikahan dan membangun keluarga Kristen yang sesuai Alkitab dan memberikan pemahaman bahwa melakukan hubungan seksual bukan dalam wadah pernikahn Kristen adalah perzinahan sehingga baik laki-laki dan perempuan perlu mengakui dosa di hadapan Allah. Sebagai kesimpulan bahwa Gereja bertanggungjawab dalam melakukan pelayanan pastoral terhadap pasangan yang hamil sebelum menikah. Gereja dalam menjalankan prinsip kasih tetap memperhatikan aturan sehingga pendewasaan warga gereja menjadi terwujud.
\end{abstract}

Kata Kunci: Konseling; Pastoral; Pernikahan; Pasangan; Pranikah 


\section{Pendahuluan}

Manusia sebagai peta dan teladan Allah yang telah rusak akibat jatuh dalam dosa. Salah satu akibatnya adalah ketidakmengertian tentang seksual yang berdampak pada penggunakaan seksual yang salah, sehingga dampaknya adalah terjadi kehamilan diluar perkawinan. Dari permasalahan di atas, gereja sebagai lembaga yang telah didirikan oleh Tuhan, dapat berkontribusi dalam menyelesaikan masalah ini. Dalam hal ini gereja bertindak melakukan pelayanan pastoral terhadap pasangan yang melakukan hubungan seksual diluar perkawinan yang menyebabkan kehamilan. Namun tugas ini tidaklah mudah, karena gereja sebagai gereja yang kelihatan memiliki peraturan dan tata tertib dalam mengatur setiap warga gereja, itu sebabnya ada gereja yang setuju tetapi juga ada gereja yang tidak menyetujui pelayanan ini dengan alasan masing-masing.

Peran serta gereja dalam menggembalakan umat Tuhan sangat diperlukan untuk mengurai persoalan dalam jemaat. Masalah ini tidak dapat dibiarkan atau didiamkan karena akan berakibat fatal bagi anggota jemaat yang lain serta pandangan dari jemaat lain. Dalam permasalah seperti ini, bagaimana kontribusi gereja terhadap pernikahan Kristen yang terjadi akibat hamil diluar nikah dan bagaimana pelayanan pastoral terhadap pasangan yang hamil diluar nikah. Karya ilmiah ini akan memaparkan prosedur pelayanan pastoral terhadap pasangan yang hamil diluar nikah.

\section{Metode Penelitian}

Isu pokok yang akan diteliti yaitu pelayanan pastoral terhadap pasangan yang hamil di luar pernikahan kudus dengan menggunakan pendekatan kualitatif, yaitu penelitian selalu dimulai dengan rasa ingin tahu (curiosity) peneliti, terhadap satu atau lebih fenomena alam atau fenomena sosial. Kuriositas itu diteruskan melalui gagasangagasan yang bersifat tentatif pada pikiran peneliti, kemudian dikonseptualisasikan apa yang dipikirkan, dirumuskan hipotesis atau asumsi, mencari dan menemukan dasar teori yang tepat dengan gagasan, isu, masalah yang peneliti pikirkan, menetapkan metode penelitian yang tepat, mengumpulkan data (kepustakaan dan data lapangan), melakukan analisa data dan interpretasi (memberi makna) pada data, dan menulis laporan penelitian.

\section{PEMBAHASAN}

\section{A. Pelayanan Pastoral}

1. Arti pelayanan pastoral

Pelayanan pastoral adalah sebuah pelayanan yang dilakukan oleh seorang hamba Tuhan yang juga berperan sebagai konselor ${ }^{1}$ bagi klien atau jemaat yang membutuhkan pelayanan $^{2}$ dan pelayanan ini dilakukan dengan penuh tanggungjawab kepada Tuhan. ${ }^{3}$

\footnotetext{
${ }^{1}$ Seorang hamba Tuhan dapat juga menempatkan diri sebagai seorang konselor yang dapat memberikan hidupnya bagi seorang klien atau jemaat yang sedang bergumul dengan masalahnya. Seorang konselor adalah seorang yang terpanggil oleh Allah dalam melakukan pelayanan konseling dan diperlengkapi dengan disiplin ilmu, sehingga ada kombinasi antara keterpanggilanya dan disiplin ilmu yang dimilikinya. Jika tidak maka akan dilakukan dengan tidak ada skill atau kemampuan dan dilakukan dengan asal-asalan atau tidak disiplin akibatnya pelayanan konseling yang dilakukan tidak efektif. Lihat Yakub B. Susabda, Pastoral Konseling 1 (Malang: Gandum Mas, 2006), 22-25.

${ }^{2}$ Pada umumnya seorang klein mencari seorang konselor karena memiliki masalah yang sudah serius atau mencari konselor karena masalah yang dihadapinya sudah acut.

${ }^{3}$ Bertanggungjawab kepada Tuhan artinya tugas dalam penggembalaan seorang hamba Tuhan adalah membimbing setiap anggota jemaatnya langkah demi langkah ke arah kematangan hidup rohaninya sehingga
} 


\section{Dasar Alkitab pelayanan pastoral}

Alkitab dengan jelas menyatakan bahwa setelah Allah menciptakan manusia, manusia ditempat di Taman Eden dan diberikan mandat untuk mengelolah dan dilarang memakan buah yang di tengah-tengah taman karena nanti mati. Perintah ini dilanggar yang mengakibatkan Adam dan Hawa berdosa, maka rusaklah relasi manusia dengan Allah. Dalam keadaan ini, Allah berinisiatif mencari manusia dan menyelamatkan manusia dengan mengutus Yesus Kristus ke dunia untuk mati dan bangkit demi memulihkan relasi antara Allah dan manusia (bdk. Yoh. 3:16; 1 Kor. 15:3-4; Ef. 2:8-9).

Dalam Perjanjian Lama, Allah menunjukkan diri-Nya dalam memimpin, memelihara dan menghibur Bangsa Israel (bdk. Yes. 40:11; Mzm. 23; Yeh. 34) ${ }^{4}$. Contohnya waktu Allah memimpin Bangsa Israel keluar dari Mesir menuju Tanah Kanaan, Allah menuntun bangsa Israel dengan tiang awan dan tiang api dalam menggembalakan orang Israel.

Dalam Perjanjian Baru, Yesus telah menunjukkan diri-Nya sebagai Gembala yang baik, yang memelihara, merawat, menuntun, menyembuhkan bahkan mengalahkan musuh umat-Nya (Yoh. 10), hal ini dibuktikan dengan Yesus menyerahkan diri-Nya sampai mati di kayu salib. Kelanjutan penggembalaan dilakukan oleh murid-murid Yesus dan oleh gereja atau orang percaya sampai hari ini dalam memelihara umat-Nya sehingga orang percaya terbina, terjaga dan terpelihara. ${ }^{5}$

\section{Tujuan pelayanan pastoral}

Dalam beberapa kasus, terjadi kehamilan diluar perkawinan kudus, dan atas dasar permintaan klien untuk mendapat pelayanan peneguhan perkawinan, maka dalam penanganan kasus ini tidaklah mudah karena klien mengharapkan secepatnya untuk mendapatkan peneguhan perkawinan dengan beberapa alasan diantaranya supaya tidak malu dan supaya tidak terlihat kehamilan karena perut semakin membesar, namun diberi penjelasan bahwa perlu melewati konseling pra-nikah, dengan beberapa tujuan, antara lain:

a. Memberikan pemahaman bahwa melakukan hubungan seksual bukan dalam wadah perkawinan Kristen adalah perzinahan sehingga baik laki-laki dan perempuan perlu mengakui dosa dihadapan Allah ${ }^{6}$. Tujuan pengakuan atas apa yang dilakukan adalah agar komitmen dalam membangun perkawinan seumur hidup tidak dapat dirusak oleh salah satu pasangan tetapi tetap setia sampai maut memisahkan ${ }^{7}$.

b. Dalam menjalani proses konseling pranikah berguna untuk memberikan pemahaman yang benar tentang hal-hal apa perlu yang dilakukan setelah menikah, jadi "dipersiapkan perkawinan seumur hidup" agar menjadi keluarga yang mengalami pemulihan dan berkomitmen untuk membangun keluarga yang menyenangkan hati Tuhan, seperti yang diungkapkan oleh John Piper bahwa, "pernikahan dirancang oleh Allah untuk memamerkan

mereka makin menjadi serupa dengan Kristus. Lihat Yakub B. Susabda, Pastoral Konseling 1 (Malang: Gandum Mas, 2006), 65.

${ }^{4}$ Daniel Ronda, Pengantar Konseling Pastoral (Bandung: Kalam Hidup, 2015), 25

${ }^{5}$ Daniel Ronda, Pengantar Konseling Pastoral (Bandung: Kalam Hidup, 2015), 25-26.

${ }^{6}$ Dosa bila dibiarkan dan tidak diselesaikan, akan membawa hal-hal yang lebih buruk lagi bagi seseorang. Ia akan kehilangan damai, ketenteraman, ketenangan dan kebahagiaan. Lihat Tulus Tu'u, Dasar-Dasar Konseling Pastoral (Yogyakarta: ANDI, 2010), 35.

${ }^{7}$ Pasangan laki-laki dan perempuan yang menikah adalah pasangan yang telah berjanji untuk terikat dalam suatu hubungan pernikahan seumur hidup, dan komitmen itu mencakup seluruh aspek kehidupannya. Lihat Vivian A. Soesilo, Bimbingan Pranikah edisi 2 (Malang: SAAT, 2013), 51-51. 
kemuliaan-Nya dengan cara yang tidak dapat dilakukan oleh peristiwa atau lembaga lainnya." 8

c. Bagaimana kedua pasangan tersebut memperhatikan kesehatan rohani, dan jasmani agar sama-sama "menjaga keutuhan keluarga" sebagai lembaga yang utama. Stevri Indra Lumintang dan Danik Astuti Lumintang9 berkata, "pernikahan tentu bukanlah hanya sebatas bertemunya dua orang yang berbeda jenis kelamin tanpa ikatan, melainkan bersatunya dua orang tersebut dalam satu ikatan oleh Tuhan Yesus Kristus menjadi satu pasang suami-isteri selamanya."

d. Memberikan pelajaran bagi jemaat lain, bahwa prilaku demikian tidak berkenan kepada Tuhan sehingga tidak boleh mengikuti sikap demikian ${ }^{10}$, terutama kepada remaja atau pemuda yang sedang berpacaran agar tahu batasan-batasan dalam berpacaran, yaitu mengetahui bahwa mata Tuhan tertuju untuk melihat apa yang dilakukan (1 Sam. 2:3), jangan merasa bahwa dengan berpacaran berarti sudah memiliki sehingga bebas melakukan apa saja, dan supaya memperhatikan norma-norma yang berlaku dalam masyarakat. ${ }^{11}$

e. Supaya dapat mengerti tentang "perkawinan yang benar" sesuai Alkitab agar membangun keluarga Kristen yang sesuai Alkitab ${ }^{12}$, bukan karena sudah terlanjur hamil sehingga tidak perlu waktu yang panjang untuk melewati konseling pranikah.

f. Dalam penanganan pelayanan pastoral terhadap perkawinan akibat kehamilan supaya dapat dilakukan dengan baik sesuai dengan aturan yang berlaku dalam gereja.

g. Memberikan pemahaman bahwa perkawinan bukan paksaan dan dipaksakan karena ada tekanan atau karena sudah terjadi kehamilan, tetapi mereka memiliki tanggungjawab karena sudah terjadi kehamilan. Gerald Corey ${ }^{13}$ berkata, "klien menerima tanggung jawab yang lebih besar atas siapa dirinya, menerima perasaan-perasaan sendiri, menghindari tindakan menyalahkan lingkungan dan orang lain atas keadaan dirinya, dan menyadari bahwa sekarang dia bertanggung jawab untuk apa yang dilakuannya."

h. Memberikan pemahaman bahwa jika tidak siap menjadi seorang ayah dan ibu sebaiknya perkawinan tidak dipaksakan karena dapat menimbulkan berbagai masalah baru dan mengakibatkan terjadi perceraian.

\section{Hambatan pelayanan pastoral}

Dalam pengalaman pelayanan, penulis menemukan beberapa hambatan, antara lain:

a. Ketidakjujuran dalam persoalan yang dihadapi karena merasa malu.

\footnotetext{
${ }^{8}$ John Piper, This Momentary Marriage (Bandung: Pionir Jaya, 2012), 23.

${ }^{9}$ Stevri Indra Lumintang dan Danik Astuti Lumintang, Theologia Pernikahan Kristen di Tengah Krisis (Jakarta: Geneva Insani Indonesia, 2016), 80.

${ }^{10}$ Karena seks dirancang oleh Tuhan dan hanya dinikmati dalam hubungan perkawinan yang sah, artinya hanya dilakukan dalam perkawinan kudus dan hanya kepada pasangan yang sah seumur hidup sehingga memperlihatkan kepada dunia sebagai suatu kesaksian. Lihat John Piper, This Momentary Marriage (Bandung: Pionir Jaya, 2012), 140-141.

${ }^{11}$ Markus Suyadi, Pernak-Pernik Pernikahan (Yogyakarta: ANDI, 2014), 19.

${ }^{12}$ Pernikahan adalah kontrak secara resmi, sosial, dan rohani antara seorang pria dan seorang wanita. Pernikahan merupakan janji ilahi yang dibuat di hadapan Allah. ini adalah komitmen satu sama lain - ikrar untuk hidup bersama, saling melayani, dan tetap setia satu sama lain. lihat Dale Mathis dan Susan mathis, Menuju Pernikahan yang Sehat dan Solid (Yogyakarta: ANDI, 2014), 12.

${ }^{13}$ Gerald Corey, Teori dan Praktek Konseling dan Psikoterapi (Bandung: Refika Aditama, 2009), 320.
} 
b. Karena sudah terlanjur hamil maka menganggap sebaiknya langsung penerima peneguhan perkawinan sehingga dalam proses konseling pranikah hanya sebatas memenuhi persyaratan tanpa penghayatan yang mendalam.

c. Ketidaksepahaman antar keluarga kedua belah pihak dan adanya stigma dalam masyarakat bahwa jika sudah hamil diluar nikah berarti sudah cemar dan tidak pantas mendapat layanan gerejawi.

\section{B. Pasangan yang hamil diluar pernikahan}

\section{Istilah hamil diluar pernikahan}

Alkitab menjelaskan bahwa sejak manusia (Adam) diciptakan oleh Allah, manusia (Adam) tidak baik hidup sendiri (Kej. 2:18) ${ }^{14}$, itu sebabnya Allah menciptakan Hawa dari tulang rusuk Adam dan memberkati Adam dan Hawa sebagai suami-isteri ${ }^{15}$. Adam dan Hawa (laki-laki dan perempuan) sebagai makhluk seksual mempertanggungjawabkannya dengan benar ${ }^{16}$.

Terjadi penyimpangan seksual sebagai akibat dari status manusia yang sudah jatuh dalam dosa. Manusia mencari kenikmatan atau kepuasan seksual di luar dari perkawinan yang sah $^{17}$, sehingga salah satu akibatnya terjadi kehamilan yang tidak diinginkan ${ }^{18}$. Persoalan ini bisa mengakibatkan ketidaksiapan laki-laki dan perempuan masuk dalam rumah tangga yang baru. Dampak dari persoalan ini yaitu adanya keterpaksaan dalam membangun rumah tangga karena kondisi si perempuan yang sudah hamil.

Perkawinan terjadi bukan karena tekanan atau paksaan atau alasan dari pihak mana pun juga tetapi atas dasar menggenapi perintah Allah dan tujuannya agar keluarga yang dibangun mempermuliakan nama Allah atau untuk menyatakan kemuliaan-Nya ${ }^{19}$. Kenyataannya ada beberapa keluarga yang melaksanakan perkawinan dan membentuk rumah tangga karena telah terjadi kehamilan. ${ }^{20}$ Meski pada awalnya belum siap membentuk keluarga yang baru, tetapi karena terjadi kehamilan maka sepasang pria

${ }^{14}$ istilah tidak baik manusia seorang diri artinya Allah menciptakan Hawa untuk bisa menjadi penolong yang sepadan bagi Adam. Lihat Sutjipto Subeno, Indahnya Pernikahan Kristen (Surabaya: Momentum, 2010), $11-12$.

${ }^{15}$ Perkawinan dirancangkan dan disatukan oleh Perancang Besar Sendiri untuk menolong Anda, memberkati Anda, menjadikan Anda pribadi yang lebih baik, memperhatikan kepada Anda bagaimana memberi dan menerima cinta, dan mengizinkan Anda berbagi sukacita yang dalam dan kekal dengan satu orang lain seumur hidup. Lihat Clayton dan Charie King, 12 Pertanyaan yang harus diajukan Sebelum Anda Menikah (Jakarta: Immanuel, 2013), xvi.

${ }^{16}$ Kinsey melaporkan bahwa $85 \%$ pria Amerika melakukan hubungan seksual sebelum menikah; $70 \%$ pria Amerika berhubungan dengan pelacur paling tidak satu kali dalam hidup mereka, $60 \%$ pria Amerika melakukan oral seks, 30-45\% pria Amerika melakukan perselingkuhan, melakukan hubungan seksual di luar pernikahan, $37 \%$ pria Amerika melakukan hubungan homoseksual paling tidak satu kali dalam hidup mereka. Andik Wijaya, Sexual Holines (Surabaya: Kenza Publishing House, 2002), 147.

${ }^{17}$ Cinta di luar perkawinan dilukiskan sebagai jalan kebodohan, yang menawarkan kenikmatan jangka pendek dengan cara yang membawa kepada "kehancuran" (sakit hati, rasa bersalah, duka) pada akhirnya. Lihat Tim dan Beverly LaHaye, Kehidupan Seks dalam Pernikahan, diterj. Gabriella K. Koswiranegara (Grand Rapids: Zondervan, 2009), 18.

${ }^{18}$ Seks itu baik karena Allah yang menciptakan seks itu adalah Allah yang baik. Dan Allah sangat dimuliakan ketika kita menerima karunia-Nya dengan rasa syukur dan menikmatinya sesuai dengan cara yang dimaksudkan-Nya. Lihat John Piper dan Justin Taylor, Seks dan Supremasi Kristus (Surabaya: Momentum, 2011), 8 .

${ }^{19}$ John Piper, This Momentary Marriage (Bandung: Pionir Jaya, 2012), 23.

${ }^{20}$ Yakub B. Susabda, dkk., Konseling Pranikah (Bandung: Mitra Pustaka, 2005), 40. 
dan perempuan dipaksa atau terpaksa untuk menikah. Berikut ini ada beberapa contoh kasus yang pernah penulis dampingi dalam konseling pranikah, antara lain:

a. Sebut saja namanya Wati. Seorang gadis sudah berpacaran dengan tetangganya sebut saja namanya Budi selama 2 tahun. Dalam berpacaran sering terjadi pertengkaran dan beberapa kali hubungan berakhir, namun hubungan akhirnya dilanjutkan kembali dengan alasan saling mencintai. Pihak keluarga wati tidak menyetujui hubungan mereka dengan alasan pendidikan Budi tidak setara dengan Wati dan pekerjaan dari sang pria tidak seperti yang diharapkan keluarga Wati. Namun Wati tidak menggubris keluarganya dan tetap melanjutkan hubunganya dengan kekasihnya ini dan sangat disayangkan Wati mengalami kehamilan akibat melakukan seks diluar nikah dengan pacarnya. Keadaan ini memaksa keluarga merelakan Wati menikah dengan pacarnya.

b. Jaka seorang perantau yang bekerja sebagai seorang karyawan swasta, berpacaran dengan kekasihnya yang sama-sama merantau dan tinggal di satu komplek rumah kos akhrinya memutuskan untuk tinggal bersama demi menghemat pengeluaran dan biaya hidup, akhirnya hamil diluar nikah dan melahirkan seorang anak dan berita itu terdengar oleh orangtuanya di kampung halaman, karena merasa malu, orangtua mengancam mereka untuk segera menikah dan mencari pendeta atau gereja yang dapat menolongnya.

c. Andhi mahasiswa berusia 21 tahun berpacaran dengan Lusi 20 tahun, hingga Lusi hamil dan akhirnya dipaksa oleh ibunya untuk menikah padahal mereka merasa belum siap dari segi mental dan finansial.

\section{Penyebab hamil diluar pernikahan}

Tuhan telah menciptakan manusia sebagai makhluk seksual. Dalam posisi ini, manusia dapat mempertanggungjawabkannya dihadapan Tuhan. Menurut Anne Krabili Hersberger dan Willard S. Krabill bahwa, "seksualitas adalah pemberian Allah dan manusia melakukan penyimpangan karena manusia mengabaikan atau tidak menghormati Allah dan tata cara hidup orang Kristen." ${ }^{21}$ Ada banyak faktor yang mempengaruhi sehingga seorang perempuan hamil diluar nikah, salah satunya yaitu dosa orang itu sendiri ${ }^{22}$ dan lingkungan yang mempengaruhinya ${ }^{23}$. Selain itu, pergaulan yang melebihi batas-batas dalam berpacaran seperti petting dan kissing ${ }^{24}$ yang menimbulkan birahi yang tidak terkontrol sehingga mengakibatkan persetubuhan yang berakibat kehamilan. Jika benar-benar saling mencintai maka laki-laki dan perempuan akan menahan diri sampai masuk dalam perkawinan kudus, tetapi jika tidak, masingmasing hanya melampiaskan birahinya atau nafsunya yang berakibat terjadi kehamilan. ${ }^{25}$

Di samping itu, perilaku seks di luar kontrol mungkin satu-satunya jawaban terbaik yang bisa ditemukan klien untuk menanggapi rasa sakit yang ada dalam dirinya ${ }^{26}$, oleh karena merasakan pengalaman masa lalu yang menyakitkan sehingga

\footnotetext{
${ }^{21}$ Anne Krabili Hersberger, Seksualitas Pemberian Allah (Jakarta: BPK. Gunung Mulia, 2008), 163.

${ }^{22}$ Berdasarkan Yakobus 1:13-14, keinginan daging yang tidak terkontrol dapat melahirkan dosa yang membawa kepada kematian.

${ }^{23}$ Daniel Ronda, Pengantar Konseling Pastoral (Bandung: Kalam Hidup, 2015), 138.

${ }^{24}$ Yakub B. Susabda, Pastoral Konseling 2 (Malang: Gandum Mas, 2011), 129-130.

${ }^{25}$ Stephen Tong, Rahasia Kemenangan Dalam Cinta dan Seks Menuju Pernikahan (Surabaya: Momentum, 2012), 121-122.

${ }^{26}$ Philip J. Henry, dkk., Buku Pegangan Konselor: kasus, catatan, dan kegiatan untuk individu (Tangerang: YAPKI, 2007), 138-139.
} 
sebagai pelariannya adalah mencari kenikmatan sesaat. Yakub B. Susabda ${ }^{27}$ berkata, "perhatian yang kurang dari kedua orangtua seringkali menghasilkan kekosongan jiwa yang para remaja tidak mampu atasi kecuali melalui tingkah laku seksual yang untuk sementara dapat memberikan kepuasan instan.

\section{Dampak hamil diluar perkawinan}

Stephen Tong ${ }^{28}$ berkata, "jangan melampiaskan seks sembarangan, karena akibat yang ditimbulkannya terlalu berat, penyesalannya terlalu dalam, dan kesedihan di dalam hati nuranimu sulit untuk dapat direkatkan dengan cinta Tuhan. Selain itu itu menurut Sutjipto Subeno ${ }^{29}$, "setelah semunya terjadi wanita itu marah, kecewa, sedih tetapi semua sudah terjadi dan tidak bisa ditarik kembali. Selanjutnya perasaan yang timbul adalah ketakutan ditinggal oleh sang kekasih yang telah merenggut keperawanannya." Berikut ini ada beberapa dampak hamil diluar perkawinan, antara lain:

a. Perasaan bersalah. Ketika "menyimpang" dari kehendak Tuhan yang sempurna, akan merasa bersalah. Namun, rasa bersalah ini tidak selalu tepat dan tidak selalu bisa hilang sendiri sekalipun kita sudah membereskan kesalahan ${ }^{30}$.

Menurut Hadi P. Sahardjo ${ }^{31}$, namun ada juga yang ketika berbuat kesalahan dan tahu kalau ia bersalah dan belum pernah membereskan dosa atau kesalahannya baik kepada Tuhan mau pun kepada manusia, seringkali akan selalu merasa dikejar perasaan bersalah.

b. Hilangnya kepercayaan terhadap diri sendiri. Artinya merasa rendah diri dan tidak merasa layak atau bangga dengan kehidupan yang dijalani setiap hari.

c. Hilang reputasi. Menyadari bahwa tidak menjadi garam dan terang bagi orang lain, selain itu tidak ada rasa percaya dari sahabat-sahabatnya.

d. Adanya gangguan psikologis. Mengalami stress yang sulit diatasi karena keadaaan yang telah dialaminya. Yakub B. Susabda32 berkata, "kepribadian yang melihat masalah sebagai gunung yang besar dan sering membayangkan kesulitan yang akan dihadapinya."

e. Kurangnya tanggungjawab spritual. Merasa bersalah dihadapan Tuhan karena sudah melanggar Firman Tuhan.

\section{Siapa yang bertanggungjawab}

Dalam keadaan ini, biasanya baik laki-laki atau perempuan saling menyalahkan. Saling menuduh dan menyerang satu dengan yang lain ingin menang sendiri, salah satunya merasa paling bersalah dan mau bertanggungjawab. Pada hal, baik laki-laki dan perempuan, sama-sama telah terbukti melakukan dosa perzinahan ${ }^{33}$ yang berakibat kehamilan diluar perkawinan. Itu sebabnya, dalam keadaan ini, tidak ada yang dapat dipersalahkan, baik laki-laki dan perempuan bertanggungjawab, sehingga tidak terjadi

\footnotetext{
${ }^{27}$ Yakub B. Susabda dkk., Konseling Pranikah (Jakarta: People Helpers Ministry Indonesia, 2005), 82.

${ }^{28}$ Stephen Tong, Rahasia Kemenangan Dalam Cinta dan Seks Menuju Pernikahan (Surabaya: Momentum, 2012), 66.

${ }^{29}$ Sutjipto Subeno, Indahnya Pernikahan Kristen (Surabaya: Momentum, 2010), 83.

${ }^{30}$ Gary Thomas, Bagaimana seandainya Tuhan merancangkan pernikahan lebih untuk menguduskan kita daripada untuk menyenangkan kita? (Yogyakarta: Gloria, 2014), 258.

${ }^{31}$ Hadi P. Sahardjo, Konseling Krisis dan Terapi Singkat (Bandung: Piner Jaya, 2008), 11-12.

${ }^{32}$ Yakub B. Susabda, Pelayanan Konseling Melalui Telepon (Yogyakarta: ANDI, 2007), 53.

${ }^{33}$ Sutjipto Subeno, Indahnya Pernikahan Kristen (Surabaya: Momentum, 2010), 86.
} 
PERAN GEREJA DALAM PELAYANAN PASTORAL TERHADAP ... (Jonidius Illu)

hal-hal yang tidak diharapkan, misalnya salah satunya mengusulkan jika berkenan dilakukan aborsi.

\section{Pelayanan pastoral terhadap pasangan yang hamil di luar perkawinan}

\section{Pro-kontra}

Terjadi pro-kontra antara satu gereja dengan gereja yang lain tentang pernikahan yang terjadi akibat kehamilan diluar pernikahan. Masing-masing gereja memiliki pemahaman yang berbeda-beda dan memiliki dasar atau sumber yang sama yaitu Alkitab, selain itu pemahaman teologi yang berbeda tentang permasalahan ini.

Ada gereja yang memiliki pemahaman bahwa jika sudah terjadi kehamilan diluar pernikahan atau sudah melakukan hubungan seks maka sebaiknya dilakukan "peneguhan perkawinan" di rumah ${ }^{34}$, tetapi juga ada gereja yang tetap melakukan pemberkatan di gereja. Alasan "peneguhan perkawinan di rumah karena sudah terjadi hubungan seksual dan si perempuan telah hamil sehingga pernikahan bukan lagi perkawinan kudus itu sebabnya dikelompokan sebagai "peneguhan perkawinan". Di sisi lain gereja yang tetap melakukan pemberkatan pernikahan di gereja dengan alasan bahwa yang penting baik laki-laki dan perempuan sudah mengakui dosa dan Tuhan sudah mengampuni sehingga dalam pelayanan pemberkatan perkawinan tidak boleh membatasi atau membuat perbedaan tempat. Semua manusia berdosa dan Tuhan menerima jika ada pengakuan.

Selain itu, ada yang tidak menyetujui perkawinan dilakukan dengan alasan bahwa jika dilakukan maka kemungkinan besar terjadi perceraian dan biarkan anak tersebut lahir dan dipelihara oleh salah satu diantara laki-laki atau perempuan sampai sampai anak itu dewasa dan memilih siapa yang mau ia ikuti.

\section{Pandangan Alkitab}

Alkitab menjelaskan bahwa manusia diciptakan untuk mengasihi Allah dan mengasihi manusia (orang lain). Manusia diberi kehendak bebas untuk mempertanggungjawabkan apa yang dilakukannya. Oleh karena itu jika manusia melakukan pelanggaran maka ia perlu jujur dan mengakuinya dihadapan Tuhan, contoh Raja Daud waktu melakukan perzinahan dengan Batsyeba (2 Sam. 11:1-27). Jadi apa pun dosa yang dilakukan wajib diakuinya dan dipertanggungjawabkan.

\section{Pandangan teologi}

Manusia menyadari bahwa seluruh organ tubuh adalah ciptaan Allah termasuk soal alat kelamin, sehingga manusia bertanggungjawab untuk merawatnya dan menjaga sebagai pemberian Allah, namun manusia dirusak oleh cara berpikir dan bersikap yang salah tentang seksual. Hal ini terjadi karena memiliki status sebagai orang berdosa, akibatnya mempengaruhi budaya, cara pandang dan berprilaku yang salah tentang seks. Setiap budaya memiliki persfektif yang berbeda tentang seksual, akibatnya dari generasi ke generasi dalam hal penerapan pun tidak menunjukkan nilai etis yang baik tentang seksualitas. Selain itu, dalam dunia post-modern ini, manusia telah dirusak dengan konsep-konsep dan manusia telah mempraktikan cara-cara yang salah dan berani mempublis dalam berbagai media, akibatnya manusia yang kurang memahami seksualitas berdasarkan Alkitab dan kurang memiliki rasa takut akan Tuhan, maka banyak manusia yang cendrung ingin tahu dan ingin melakukannya, sehingga terjadi penyimpangan.

\footnotetext{
${ }^{34}$ Markus, Pernak-Pernik Pernikahan (Yogyakarta: ANDI, 2010), 43.
} 
Prinsipnya adalah seksualitas sebagai pemberian Allah, yang membuat manusia menjadi gembira, menyembuhkan, kasih, pemeliharaan, dan tidak mementingkan diri sendiri yang sesungguhnya. Namun sebagai pemberian Allah, telah dirusak oleh keinginan manusia yang tidak takut akan Allah dan sengaja melakukan pelanggaran yang secara aturan telah melanggar Firman Tuhan, sehingga seksualitas menimbulkan kesengsaraan, kesakitan, dan penderitaan yang sering disebabkan oleh manusia menyalahgunakan seksualitas. ${ }^{35}$

\section{Sikap gereja}

Gereja tidak memiliki hak untuk menghakimi atau mempersulit dalam pelayanan ini. Gereja berusaha untuk membantu agar menemukan jalan keluar tetapi bersikap adil, sehingga beberapa konsekuensi tetap dijalankan. Hal ini menjadi sebuah peraturan yang diketahui semua warga gereja. Tujuannya adalah mendewasakan warga gereja agar hidup dalam ketaatan pada Firman Tuhan, dalam hal ini menjaga kekudusan hidup sebelum masuk dalam perkawinan kudus.

Gereja memiliki tanggungjawab dalam melakukan pelayanan konseling dengan harapan bahwa semua masalah-masalah dalam jemaat dapat teratasi. Menurut John F. MacArthur dan Wayne A. Mack ${ }^{36}$ bahwa, "Gereja setempat adalah wahana yang disahkan oleh Kristus untuk membantu kaum beriman bertumbuh menjadi lebih menyerupai. Gereja setempat adalah satu-satunya organisasi - atau lebih baik disebut sebagai organisme - yang dijanjikan akan dibangun-Nya, dipertahankan-Nya, serta digunakanNya. Konseling merupakan bagian penting dari pelayanan gereja setempat, karena konseling merasul serta membantu kaum beriman menjadi dewasa dalam citra Kristus.

5. Pendekatan pastoral terhadap pasangan yang hamil diluar perkawinan

Berikut ini ada beberapa pendekatan pastoral terhadap pasangan yang hamil di luar perkawinan antara lain:

a. Memperkenalkan Yesus Kristus. Jika salah satu pasangan belum menerima Yesus Kristus secara pribadi, maka inilah saatnya memperkenalkan Yesus Kristus dan mengundangnya untuk menerima Yesus Kristus supaya keluarga yang akan dibangun berdasarkan iman kepada Yesus Kristus.

b. Menuntun untuk mengakui dosa yang telah dilakukan. Pengakuan atas dosa perzinahan yang dilakukan penting karena dengan demikian ada kejujuran atas dosa yang sudah dilakukan, ada kesadaran bahwa dosa perzinahan tidak terulang lagi dan ada komitmen untuk hidup dalam kekudusan (bdk. 1 Yoh. 1:9).

c. Melakukan konseling pranikah. Dalam penerapan aturan yang dilakukan selama ini gereja bahwa setiap jemaat yang ingin mendapatkan pelayanan pemberkatan nikah kudus atau peneguhan pemberkatan akan melewati konseling pranikah. Tujuannya yaitu mempersiapkan pernikahan seumur hidup yang akan dijalani.

d. Melakukan peneguhan perkawinan. Bagi pasangan yang sudah mengikuti konseling pranikah dan telah diumumkan dalam kebaktian minggu berturutturut dua atau tiga kali, maka akan diadakan peneguhan perkawinan di rumah.

\footnotetext{
${ }^{35}$ Anne K. Hershberger, Seksualitas Pemberiaan Allah (Jakarta: BPK. Gunung Mulia, 2008), 6.

${ }^{36}$ John F. MacArthur dan Wayne A. Mack, Pengantar Konseling Alkitabiah (Malang: Gandum Mas, 2002), 366.
} 
PERAN GEREJA DALAM PELAYANAN PASTORAL TERHADAP ... (Jonidius Illu)

e. Mendamping pasca peneguhan perkawinan. Setelah mendapatkan pelayanan peneguhan perkawinan, maka pasangan tersebut tetap mendapat pendampingan guna dalam kedewasaan memahami dan penerapkan dalam rumah tangga yang baru tersebut serta belajar menyelesaikan masalahmasalah yang timbul.

\section{Kesimpulan}

1. Gereja bertanggungjawab dalam melakukan pelayanan pastoral terhadap pasangan yang hamil sebelum menikah.

2. Gereja dalam menjalankan prinsip kasih tetap memperhatikan aturan sehingga pendewasaan warga gereja menjadi terwujud dalam iman yang berkualitas.

3. Salah satu fokus pelayanan gereja adalah mempersiapkan keluarga Kristen yang hidup benar melalui konseling pra-nikah. Pernikahan hendaknya dipersiapkan untuk dijalani seumur hidup.

4. Upaya gereja dalam mewujudkan warga gereja yang hidup kudus salah satunya adalah dengan memberi pengajaran tentang cinta dan memilih pasangan yang sesuai Alkitab sehingga warga gereja tidak melakukan dosa perzinahan dan melakukan hubungan seksual di luar pernikahan yang berdampak terjadinya kehamilan sebelum menikah. 


\section{Referensi}

Clayton dan Charie King, 12 Pertanyaan yang harus diajukan Sebelum Anda Menikah (Jakarta: Immanuel, 2013)

Corey, Gerald, Teori dan Praktek Konseling dan Psikoterapi (Bandung: Refika Aditama, 2009)

Henry, Philip J., dkk., Buku Pegangan Konselor: kasus, catatan, dan kegiatan untuk individu (Tangerang: YAPKI, 2007)

Hersberger, Anne Krabili, Seksualitas Pemberian Allah (Jakarta: BPK. Gunung Mulia, 2008)

MacArthur, John F. dan Wayne A. Mack, Pengantar Konseling Alkitabiah (Malang: Gandum Mas, 2002)

Markus, Pernak-Pernik Pernikahan (Yogyakarta: ANDI, 2010)

Mathis, Dale dan Susan mathis, Menuju Pernikahan yang Sehat dan Solid (Yogyakarta: ANDI, 2014)

Lumintang, Stevri Indra dan Danik Astuti Lumintang, Theologia Pernikahan Kristen di Tengah Krisis (Jakarta: Geneva Insani Indonesia, 2016)

Piper, John, This Momentary Marriage (Bandung: Pionir Jaya, 2012)

Piper, John dan Justin Taylor, Seks dan Supremasi Kristus (Surabaya: Momentum, 2011)

Ronda, Daniel, Pengantar Konseling Pastoral (Bandung: Kalam Hidup, 2015)

Sahardjo, Hadi P., Konseling Krisis dan Terapi Singkat (Bandung: Piner Jaya, 2008)

Soesilo, Vivian A., Bimbingan Pranikah edisi 2 (Malang: SAAT, 2013)

Subeno, Sutjipto, Indahnya Pernikahan Kristen (Surabaya: Momentum, 2010)

Susabda, Yakub B., Pastoral Konseling 1 (Malang: Gandum Mas, 2006)

Susabda, Yakub B., dkk., Konseling Pranikah (Bandung: Mitra Pustaka, 2005)

Susabda, Yakub B., Pastoral Konseling 2 (Malang: Gandum Mas, 2011)

Susabda, Yakub B., Pelayanan Konseling Melalui Telepon (Yogyakarta: ANDI, 2007)

Susabda, Yakub B. dkk., Konseling Pranikah (Jakarta: People Helpers Ministry Indonesia, 2005)

Suyadi, Markus, Pernak-Pernik Pernikahan (Yogyakarta: ANDI, 2014)

Thomas, Gary, Bagaimana seandainya Tuhan merancangkan pernikahan lebih untuk menguduskan kita daripada untuk menyenangkan kita? (Yogyakarta: Gloria, 2014)

Tim dan Beverly LaHaye, Kehidupan Seks dalam Pernikahan, diterj. Gabriella K. Koswiranegara (Grand Rapids: Zondervan, 2009)

Tong, Stephen, Rahasia Kemenangan Dalam Cinta dan Seks Menuju Pernikahan (Surabaya: Momentum, 2012)

Tu'u, Tulus, Dasar-Dasar Konseling Pastoral (Yogyakarta: ANDI, 2010)

Wijaya, Andik, Sexual Holines (Surabaya: Kenza Publishing House, 2002) 